\title{
Kudüs Katliamı Bağlamında Haçlı Seferlerinin Sebepleri
}

\section{Ziya POLAT*}

Causes of the Crusades in the context of Jerusalem Massacre

Citation/@: Polat, Ziya, (2019). Causes of the Crusades in the context of Jerusalem Massacre, Milel ve Nihal, 16 (1), 175-198.

Abstract: The crusades come to the agenda with the claims of the rescue of the holy land or the crusaders' pursuit of material interests. However, while these two reasons were discussed, the massacres during the expeditions were consciously ignored by some historians. The Western-centered understanding of history has built events or phenomena as they wish: highlighting the issues that they deem valuable for themselves, leaving out the experiences that they thought would be counted against them in the margins of history. Considering this aspect, the crusades consist of a chain of important events that reveal the genocidal nature of regardless of the actual reasons. The aim of this article is to examine the reasons of the Crusades through the massacre which have taken place in Jerusalem. As the main sources of this study will be the crusading chronicles, both the objectives at the starting point of the campaigns will be easily determined and the reality of the objectives will be tested on the basis of their advent. Thus, the massacres of the crusaders in Jerusalem will be discussed as well as making more apparent the reasons of the aims of the crusades.

Keywords: The Crusades, Jerusalem, Massacre, Historians of the Crusades, Muslim historians.

Atıf/C: Polat, Ziya, (2019). Kudüs Katliamı Bağlamında Haçlı Seferlerinin Sebepleri, Milel ve Nihal, 16 (1), 175-198.

0̈z: Haçlı seferleri kutsal toprakların kurtarılması veya haçlıların maddi menfaat peşinde koşma iddialarıyla gündeme gelmektedir. Oysa bu iki sebep

* Dr. Öğr. Üyesi, Mardin Artuklu Üniversitesi, Edebiyat Fakültesi, Tarih Bölümü, [polatzypolat@gmail.com]. 
tartışıırken seferler boyunca yapılan katliamlar bazı tarihçiler tarafından bilinçli bir şekilde gözden ırak tutulmuştur. Batı merkezli tarih anlayışı olayları veya olguları istediği gibi inşa etmiş, kendileri açısından değerli gördükleri konuları ön plana çıkarmış, aleyhlerine olacağını düşündükleri yaşanmışlıkları da tarihin tozlu sayfaları arasına terk etmiştir. Bu yönüyle düşünüldüğünde haçlı seferleri sebepleri ne olursa olsun katliamcı tabiatı gözler önüne seren önemli olaylar zincirinden oluşmaktadır. Bu makalenin amacı haçlı seferlerinin sebeplerini Kudüs katliamı üzerinden irdelemektir. Çalışmanın ana kaynaklarını haçlı vakayinameleri oluşturacağından hem seferin başlangıç noktasındaki amaçları kolayca tespit edilebilecek hem de vardığı yerde yapılanlar üzerinden amaçlarının gerçekliği test edilmiş olacaktır. Böylece haçlıların Kudüs'te yaptığı katliam gözler önüne serileceği gibi haçlı seferlerinin sebepleri veya amaçları da daha görünür hale gelmiş olacaktır.

Anahtar Kelimeler: Haçlı Seferleri, Kudüs, Katliam, Haçlı Tarihçileri, Müslüman Tarihçiler.

\section{Giriş}

Haçlı seferleri; Müslüman-Hristiyan ilişkileri bağlamında tarihin dönüm noktalarından birini oluşturmaktadır. İslam'ın doğuşundan kısa bir süre sonra Müslümanların dönemin iki süper gücünden biri olan Sasani İmparatorluğunu tarih sahnesinden silmesi, diğerini de Anadolu ve Batı'daki topraklara sıkıştırması böylece bilinen dünyanın büyük bir kısmına hükmetmesi, Batı Hıristiyan dünyasında tepkilerin ortaya çıkmasına ve bazı önlemlerin alınmasına sebep olmuştu. Buna rağmen kısa ve orta vadede verilen tekiler herhangi bir sonuç doğurmamış; fakat uzun vadede önce Endülüs'te Reconquista ardından da haçlı seferleri ile Doğu Akdeniz'de Müslümanlara karşı netice elde etmişlerdi. Makale Batı Hristiyan dünyasının papanın çağrısıyla gerçekleştirdiği Birinci Haçlı Seferi'nin sebeplerini Kudüs'te yapılan katliam üzerinden değerlendirecektir.

Haçlıların Doğu Akdeniz'e niçin geldikleri çeşitli tartışmalara sebep olmuştur. Fakat iki tarafı ilgilendiren bu olaylar dizisi hakkında modern dönemde yapılan çalışmalar daha çok batı merkezli icra edilmiştir. Bu da konu hakkında tek taraflı bakış açısının egemen olmasına neden olmuştur. Dolayısıyla söz konusu bakış açısı birçok soru ve sorunun oluşmasına sebep olmaktadır. Bunlar içerisinde en çok tartışılan konuların başında haçlı seferlerinin niçin yapıldığı sorusu yer almaktadır. Problem hakkında yapılan tartışmalar güncelliğini korumakta ve birçok yeni metin ortaya çımaktadır. Fakat bu metinlerin batı merkezli olması yeni sorunlara sebep olmakta, böylece tek taraflı bakış açısını pekiştirmektedir. Bu 
durum İslam dünyasında konu ile alakalı çalışmaların yetersiz olmasından kaynaklanmaktadır.

Makalede haçlı seferlerinin sebepleri; bölgeye geldiklerinde haçlıların yaptıkları, tavırları ve davranışları üzerinden sorunsallaştırılarak ele alınacaktır. Bu çerçevede Kudüs'te yaşananlar önemli veriler sunmaktadır. Haçlıların şehirdeki uygulamaları, İslam ve Müslüman algılarıyla doğru orantılıdır. Algıdaki olumsuzluk şiddetin boyutlarını derinden etkilemiştir. Makalede haçlıların şehirde yaptıkları katliam ve cesetler üzerinde uyguladıkları vahşet, bölgeye geliş amaçları ve haçlı seferlerinin sebepleri çerçevesinde analiz edilecektir. Böylece tartışma farklı bir boyuttan gündeme taşınmış olacaktır.

Haçlıların Kudüs'te yaptıkları katliam Müslüman görgü şahitleri üzerinden kaynaklara geçirilememiştir. Çünkü şehirdeki insanların tamamı -Vali İftiharüddevle ve maiyeti hariç- katledilmiş, böylece orada yaşananları anlatacak Müslüman bir göz hayatta kalmamıştır. Bu durum başlı başına şehirde nasıl bir vahşetin uygulandığının en büyük şahididir. Dolayısıyla konu ile ilgili tartışmalar haçlı kronikleri üzerinden yapılacaktır. Çünkü Kudüs'te yaşananlarla ilgili sadece haçlıların şahitlikleri günümüze ulaşmıştır. Bunlar o gün yaşananları kısmen de olsa aydınlatmakta ve haçlıların bölgeye geliş amaçlarını anlamaya yardımcı olacak ipuçları sunmaktadır. Bu yönüyle de makale faklı veriler sunacaktır. Öte yandan metodolojik açıdan argümanları sağlam temellere oturtmak için dönemin Müslüman kaynaklarının yazdıkları haçlı kronikleri ile karşılaştırılacak, böylece konu farklı açılardan tartışılacaktır. Fakat Müslüman tarihçilerin yazdıklarının daha çok ikinci elden bilgiler üzerinden özet olarak verildiği ifade edilmelidir.

\section{Haçlı seferlerinin sebepleri}

Haçlı seferleri sebepleri bağlamında birçok tartışmaya neden olmaktadır. Haçlı kronikleri bağlamında düşünüldüğünde haçlı seferlerinin sebeplerinin ana temasının dini sebepler olduğu görülecektir. Özellikle birinci sefere katılan din adamları bunu sık sık vurgulama zorunluluğu hissetmektedirler. Kaynaklar bu düşünceyi Papa II. Urbanus'un 27 Kasım 1095 tarihinde ${ }^{1}$ Clermont Konsili'nde yaptığı konuşmaya dayandırmaktadırlar. Buna göre dini

1 Peter Lock, The Routledge companion to the crusades (London; New York: Routledge, 2006), s. 20. 
tema üç temel esas üzerinden inşa edilmektedir. Birinci tema Hıristiyanların kutsal topraklarının Müslümanların işgali altında olduğu iddiasıdır. Bu durum haçlılar için büyük bir züldür ve tanrının doğduğu ve önemli hadiselerin gerçekleştiği yerler acilen Müslümanların boyunduruğundan kurtarılmalıdır. ${ }^{2}$ Dini saikin ikinci teması da Müslümanların işgali altında olan yerlerdeki Hıristiyanlar zulme uğramakta, dolayısıyla güçlü ve üstün olan Batılı Hıristiyanlar onları kurtarmak için elinden gelen bütün çabayı göstermeleri gerektiği düşüncesi üzerine bina edilmektedir. Aksi halde görevlerini yerine getirmeyerek tanrının iradesine karşı gelmiş olacaklardır. ${ }^{3}$ Kaynaklarda haçlı seferlerinin dini sebebi olarak gösterilen diğer bir neden Müslümanların, Batılı Hıristiyanların kutsal beldeleri ziyaret edip haccetmelerine engel olmaları olarak tasvir edilmektedir. Özellikle Willermus bu durumu acınacak bir şekilde tasvir edip haçlı seferini haklı sebeplere dayandırmaya çalışmaktadır. ${ }^{4}$ Bunun için de her genç Hıristiyanların yolda çekecekleri sıkıntıları göze alarak mutlaka sefere katılmaları gerektiğini ifade etmektedir. ${ }^{5}$

Haçlılar bölgeye kalıcı olma düşüncesiyle gelmişlerdi. Bunun için de ele geçirdikleri şehirlere yerleşebilmeleri için şehir halkını

2 Urfalı Mateos - Papaz Grigor, Urfalı Mateos Vekayi-Nâmesi (952-1136) ve Papaz Grigor'un Zeyli (1136-1162), trc. Hrant D. Andreasyan (Ankara: Türk Tarih Kurumu, 2000), s. 188; Tyrensis Willermus, Willermus Tyrensis'in Haçl Kroniği Başlangıçtan Kudüs'ün Zaptına Kadar, trc. Ergin Ayan, 1. Bs (İstanbul: Ötüken Neşriyat, 2016), ss. 50-51; Ernoul, Haçl Seferleri Tarihi Selahaddin Eyyubi ve Kudüs'ün Fethi, trc. Ahmet Deniz Altunbaş (Kronik Kitap, 2019), s. 21; Işın Demirkent, “Haçlı Seferleri Düşüncesinin Doğuşu ve Hedefleri", Tarih Dergisi / Turkish Journal of History, 35 (1994) s. 67. Demirkent makalede dini motifin itici bir güç olduğu, seferin aslında siyasi, sosyal ve ekonomik sebeplere dayandığı tezini ileri sürmektedir. Nitekim Papa II. Urbanus'un konuşmasına bakıldığında kutsal toprakların işgal altında olduğu vurgusunun arka planda kaldığı görülmektedir.

3 Carnotensis Fulcherius, Kudüs Seferi Kutsal Toprakları Kurtarmak, çev.: İlcan Bihter Barlas, 1. bs (İstanbul: IQ Kültür Sanat Yayıncllık, 2009), s. 50.

4 Willermus, Haçlı Kroniği, ss. 42-43; Steven Runciman, Haçlı Seferleri Tarihi, 4. Bs (Ankara: Türk Tarih Kurumu, 2008), 1: 84. Anna Kommena benzer bir efsaneyi Pierre Hermit' üzerinden anlatır. Buna göre ünlü keşiş Kudüs'ü ziyaret etmek istemiş fakat Müslümanlar buna engel olmuştu. Bunun üzerine Pierre Batı'ya dönüp vaazlar vererek Kutsal toprakları Sarazen ve Türklerden kurtarmak için Hristiyanları sefere ikna etmiştir. Görüldüğü üzere bu anlatıda Papa II. Urbanus herhangi bir şekilde yer almamaktadır (Anna Komnena, Alexiad Malazgirt'in Sonrası İmparator Alexios Komnenos Döneminin Tarihi, trc. Bilge Umar (İstanbul: İnk1lap Kitabevi, 1996), s. 303.

5 Anonim, Anonim Haçl tarihi, çev.: Ergin Ayan (İstanbul: Selenge Yayınları, 2013), s. 50. 
kılıçtan geçirmeleri gerekmekteydi. Nitekim Kudüs dahil girebildikleri bütün şehirlerin halklarını katletmekten çekinmemiş hatta bunu görev bilinciyle yerine getirmişlerdi. Dolayısıyla haçlılar dini saiklerden ziyade toprak ve şehirler elde etmek, dolayısıyla zenginliklere sahip olmak için bölgeye gelmişlerdi. Çünkü onlar bu toprakların kendilerine ait olduğunu, Müslümanların buraları zulüm ve haksızlıklar yoluyla ellerinden aldıklarını, hatta bunun da ötesine geçerek söz konusu toprakların kendi anavatanları oldukları inancına sahiplerdi. Çünkü onlara göre Tanrı ilk insanı burada yaratmıs, insanoğlu buradan yeryüzüne yayılmıştır. ${ }^{6}$

Haçlı seferleri esnasında yazılan kroniklere bakıldığında oldukça yoğun bir dini hissiyatın olduğu görülmektedir. Bunun sebebi kronik yazarlarının neredeyse tamamının din adamlarından oluşmasından kaynaklanmaktadır. Söz konusu metinler haçlı seferlerinin pür dini amaçlar uğruna yapıldığı izlenimi vermektedir. Fakat metinlerdeki detaylara bakıldığında sefer katılan haçlıların büyük kısmının hatta liderlerin neredeyse tamamının dini amaçlardan ziyade maddi menfaat ve güç elde etme amaciyla seferlere katıldığ1 görülmektedir. Mesela birinci haçlı seferinin liderlerinden olan Tankred'in Kudüs'te katliam işlerini bitirdikten sonra diğer liderlerden erken davranarak kutsal mekanlardaki altın, gümüş ve mücevherleri ganimet olarak aldığını fakat daha sonra bunları iade ettiği ifade edilmektedir.7 Kroniklerin hiçbirinde ifade edilmemiş olmasına rağmen Tankred'in söz konusu ganimeti iade ermesi aldığı tepkilerden sonra olmalıdır. Çünkü haçlılar şehre girmeden önce evlerin nasıl paylaşılacağı konusunu konuşmuş, fakat ganimetler hakkındaki tartışmalar sonuçlandırılamamıştı. Dolayısıyla kutsal mekanlardan elde edilen ganimet, Kudüs'ü kimin nasıl yöneteceğinde olduğu gibi, tartışma konusu olmuş, Tankret söz konusu ganimetleri teslim etmek zorunda kalmıştı. Dolayısıyla kroniklerde ifade edilen pür dini amacı olduğu gibi kabullenmek büyük sorunlar oluşturacaktır.

6 Fulcherius, Kudüs Seferi, s. 106.

7 Willermus, Haçlı Kroniğ i, s. 363. 


\section{Kudüs Katliamı}

Haçlılar dağlık bir bölge üzerinde kurulmuş olan Kudüs'ün önlerine geldiklerinde takvim 7 Haziran 1099 tarihine işaret etmekteydi. ${ }^{8}$ Haçlılar Seferin başlamasından üç yıl sonra zorlanarak da olsa, yabancısı oldukları bir coğrafyada sırasıyla İznik, Urfa, Antakya ve Maarratünnuman gibi şehirleri almış, büyük bir öz güven elde etmişlerdi. Kudüs önlerinde karargâh kurduklarında içerde hazırlık yapmış savunmacılara ve sağlam surlarına rağmen şehri alacaklarına kesin bir şekilde inanmaktaydılar. Çünkü Tanrı'nın emriyle sefere çıkmış ve onun inayetiyle Kudüs surlarının önüne kadar gelmişlerdi. Onları buraya kadar getiren kuvvet şehri almalarına da mutlaka yardım edecekti. Bunun da ötesinde şehre hâkim olmaları onlar için Tanrı'nın vadiydi ve bunun gerçekleşmesi d1Şında bir seçenek yoktu. ${ }^{9}$

Haçlılar şehrin önüne geldikleri ilk gün kuşatmayı başlatmışlardı. Fakat Zeytin dağındaki bir keşişin 1srarlarıyla bir müddet beyhude devam ettirdikleri saldırıya, kuşatma aletlerinin yetersiz olduğu anlaşılınca, 12 Haziran tarihinde ara verildi. Çünkü surların arkasında savunma yapanlar savaş teçhizatı bakımından onlardan daha iyi durumdaydı. Haçlılar mancınıklarla surları dövseler de bunların yeterli olmadığı ortaya çıkmıştı. Dolayısıyla kuşatmayı kırabilecek malzemeye ihtiyaçları vardı. Nitekim 15 haziranda toplanan savaş konseyinde yeterli teçhizat hazırlanmadan bir daha saldırmamaya karar verilmişti. Bunun için de savunmadakilerle aynı şartlarda mücadele edebilecek ve surları aşmada onlara yardımcı olacak ateşe dayanıklı kuleler, daha fazla mancınık ve firsat bulduklarında surlara tırmanmak için merdivenler inşa etme amacıyla yoğun bir hazırlık sürecine girilmişti. ${ }^{10}$ Fakat ellerinde yeterince malzeme olmayınca söz konusu ihtiyaçları temin etmek için çevreye asker göndermek zorunda kalmaktaydılar. Bu durumdan haberdar olan şehirdeki Müslüman garnizon haçlılara zarar vermek

8 Fulcherius, Kudüs Seferi, s. 99. Anonim Haçlı Tarihi ve Guibert de Nogent 6 Haziran tarihlerin verirler (Anonim, Anonim Haçlı tarihi, s. 151; de Nogent Guibert, The Deeds of God Through the Franks: A Translation of Guibert de Nogent's Gesta Dei Per Francos, trc. Robert Levine (Boydell \& Brewer Ltd, 1997), s. 126).

9 Raimundus Aguilers, Haçlılar Kudüs'te Bir Papazın Gözünden İlk Haçlı Seferi, çev.: Süleyman Genç (Yeditepe Yayınevi, 2019), s. 201, 202; Fulcherius, Kudüs Seferi, s. 102, 103.

10 Runciman, Haçlı Seferleri Tarihi, 1: 217. 
için geçitlere, su kenarlarına ve malzeme bulabilecekleri yerlere birlikler gönderip saldırılar düzenleyip onları yıpratıyorlardı. Müdafilerin bu taktiği haçliların birçok kayıp vermelerine sebep olmuş, özellikle suya ulaşmalarını neredeyse imkânsız hale getirmişti. ${ }^{11}$ Haçlıların çaresizlik içinde kıvrandıkları bir anda Yafa'ya gelen yardım gemileri erzak, askeri malzeme ve teçhizat hazırlayacak ustalar getirmişti. Haçlılar zorlanarak da olsa bu yardımların Kudüs önlerine ulaşmasını sağladılar. Yardımın gelmesiyle birlikte çevreden edindikleri ahşap malzeme ile savaş aletlerini yapmayı başardılar. Ardından kuleleri ve diğer savaş aletlerini uzun araştırmalar sonucu şehir surlarının zayıf olduğunu düşündükleri bölgelere taşıyıp monte ettiler. Bu işlemi pazarı pazartesiye bağlayan gece tamamlamışlardı. Öte yandan sabahleyin şehir surlarının savaş aletleri ve kulelerle kuşatıldığını gören Müslümanlar dehşete düşmüş, fakat soğuk kanlılıklarını kaybetmeyerek surların zayıf yerlerini güçlendirmeye ve gerekli önlemleri almaya başlamışlardı. Haçlılar savaş aletlerini aniden savunmacıların karşısına çıkarmakla psikolojik üstünlüğü ele geçirdiklerini fark etmiş, fakat sıkı bir şekilde çalışmaya devam ederek saldırıyı tekrar başlattıkları tarihe kadar hazırlıklarını en iyi düzeye getirmişlerdi. ${ }^{12}$ Çarşamba gece saatlerinde başlattıkları son saldırı ile birlikte Godefroi, Raymond ve Tankret liderliğinde haçlılar büyük sıkıntılarla sürdürdükleri bir buçuk aylık kuşatma ve saldırı sonunda 15 Temmuz 1099 Cuma günü öğle saatlerinde şehre girmeyi başardılar. ${ }^{13}$ Fulcherius bu anı heyecanlı bir şekilde anlatmaktadır:

“Böylece Haçlılar öğle vakti şehre girmeyi başardılar. Tanrı bize yardım et! diyerek saldırıya geçen adamlarımızın ilk işi bayrağımızı surların üstüne dikmek oldu. Dehşet içineki kâfirler ise şehrin dar sokakları boyunca kaçışıyor Haçlılar da hızla onların peşine düşüyordu" ${ }^{14}$

11 Albert of Aachen, Historia Ierosoliminata: History of the Journey to Jerusalem, çev.: Susan B. Edgington (Oxford: Oxford University Press, 2007), s. 411; Anonim, Anonim Haçl tarihi, s. 152; Aguilers, Haçllar Kudüs'te, 191-192; Guibert, The Deeds of God Through the Franks, s. 128.

12 Guibert, The Deeds of God Through the Franks, ss. 127-129.

13 Aguilers, Haçllar Kudüs'te, s. 203; Fulcherius, Kudüs Seferi, s. 104; Anonim, Anonim Haçl tarihi, s. 155.

14 Fulcherius, Kudüs Seferi, s. 104. 
Haçlılar kuşatma boyunca çok büyük sıkıntılar çekmiş, açlıktan ve susuzluktan telef olacak duruma gelmişlerdi. Kaynaklar susuzluk sebebiyle yaşananları büyük bir acıyla tasvir etmektedir. Öyle ki Haçlılar susuzluktan birbirlerine düşmüş, hatta bazen aralarında savaşmış, bu durum abartılı da olsa haçlıların asker sayısının azalmasına sebep olmuştu. Muhasaracılar susuzluklarını gidermek için öküz ve manda derilerini birbirine dikerek karargâha su taşımak için kullanmış fakat bu şekilde karargâha gelen su bozulduğu için çektikleri sıkıntı katlanarak devam etmişti. ${ }^{15}$ Bütün olumsuzluklara rağmen her seferinde din adamlarının motive etmesi sonucu haçl1lar yeniden savaşa sarılmışlardı. Din adamlarının sefer boyunca başvurdukları efsaneler gerçek anlamda motivasyonu sağlamış ve haçlıların başarılarında büyük bir paya sahip olmuştu. Mesela Adhemar olayı bunun en iyi örneklerinden biridir. 6 Temmuz'da bir papaz önceki yıl ölmüş olan Adhemar'ın kendisine göründüğünü, haçlı liderlerinin bencilliği, hilekarlığg ve riyakarlığı bir tarafa bırakıp üç gün oruç tutup pişmanlık içerisinde Kudüs'ün etrafını yalın ayak dolaşarak dünyanın pisliklerinden/kirlerinden temizlenmeleri halinde şehri dokuz gün içerisinde zapt edecekler, aksi halde çekecekleri sıkıntı daha da artacaktı. ${ }^{16}$ Haçlı kaynakları benzer bir olayın saldırı başladıktan sonra da yaşandığını iddia etmektedir. Buna göre şiddetli saldırılara rağmen herhangi bir sonuç elde edemeyince kuşatmayı bırakacakları anda Zeytin Dağı'nda parlak kalkanıyla çıkagelen ve daha sonra ortadan kaybolduğu söylenen meşhur bir savaşçı, haçlıların saldırıyı kararlı bir şekilde sürdürmelerine yol açmıştı. ${ }^{17}$ Anlatılan efsanevi olaylardan din adamlarının kitle psikolojisini çok iyi yönlendirdikleri anlaşılmaktadır. Haçlıların elde ettikleri başarı sadece din adamlarının psikolojik başarıları sonucu

Anonim, Anonim Haçl tarihi, s. 153; Aguilers, Haçllar Kudüs'te, s. 192; Willermus, Haçlı Kroniği, ss. 339-340. şehrin düşüşünü daha mantıklı bir şekilde açıklamaktadır. Buna göre Müslümanlar haçlıların yaptıkları kulelerin surlara yanaştırılmasına engel olamamış, surlardan daha yüksek olan bu kulelerden atılan yanan odun parçaları yangın çıkarmış, bu şeklide o kısımda savunma yapan garnizon dumandan etkilenerek geri çekilmek zorunda kalmıştı. Bunun üzerine kulenin üzerinde bulunan haçl1lar kurdukları merdiven sayesinde surla kule arasındaki bağlantıyı sağlamış, böylece haçlı askerleri şehre girmeyi başarmışlardı (Fulcherius, Kudüs Seferi, s. 103-104). 
elde edilmedi. Bazen de umutlarını kestikleri anda gelen yardımlar onlara heyecan vermiş, yeni bir başlangıç yapar gibi kuşatmayı sürdürüp son saldırı için hazırlıklarına devam etmişlerdi. Özellikle Ceneviz filosunun Yafa'ya yardım getirmesi, gelenlerin mancını ve kule gibi büyük savaş aletlerini yapan ustalar olması ve kendileriyle getirdikleri malzemenin bu iş için kullanılması, haçlı ordusunun psikolojik açıdan üstünlüğü ele geçirmesinde etkili oldu. ${ }^{18}$ Zaten yardımın gelmesinden kısa bir süre sonra da Kudüs işgal edildi. Willermus şehre giren ilk kontların ve askerlerin yaptıklarını şöyle tasvir etmektedir:

“Dük ve yanındakiler derhal kınından çekilmiş kılıçları, kalkanları ve miğferleriyle mücehhez olarak sokaklara ve şehrin meydanlarına giderek, yaş ve cinsiyete bakmaksızın buldukları bütün düşmanları kılıçtan geçirdiler. Her tarafta o kadar çok insan kellesi yığıldı ki, cesetlerin üzerinden başka geçecek yol kalmadi."19

Haçlılar arasında surlara ilk çıkan Çiçek kapısı ile Yafa kapısı arasında kuşatmayı sürdüren Godefroi de Bouillon maiyetinde bulunan Litold ve Gilbert de Tournai adındaki iki Flaman şövalyesi olsa da şehre girip katliama başlayan ilk şahıs Flandre Kontu ve Normandia Dükü olan Tankred idi. O ve diğer şövalyeler adeta delirmiş gibi şehre girmişlerdi. Godefroi surların üstüne çıktıktan sonra askerlerinin kendisini takip etmeleri ve kolayca şehrin içine girmelerini sağlamak için surların üstünde bekleyerek şehre daha fazla asker girmesini sağlamaya çalışıyordu. ${ }^{20}$ Zaten çok sürmeden şehir haçlı askerleriyle dolmuş, müdafiler, kadın ve çocukların uğradıkları vahşet karşısında neye uğradıklarını şaşırmışlardı. Şehrin güney cephesindeki Davut Kulesinde İftiharüddevle ile mücadeleye devam eden Raymond, haçlıların şehre girdiğini biraz geç fark etmiş ama o da diğerlerinden farklı bir tavır takınmayıp şehre girdiği anda katliama başlamıştı:

"Şehrin bir başka köşesinde mücadele eden Raymond ve adamlarıysa Müslümanların surların üstünden atladıklarını

18 Guibert, The Deeds of God Through the Franks, ss. 127-128; Anonim, Anonim Haçlı tarihi, s. 152; Willermus, Haçh Kroniği, ss. 341-343; Runciman, Haçlı Seferleri Tarihi, 2008, 1: 217.

19 Willermus, Haçlı Kroniğ i, s. 361.

20 Anonim, Anonim Haçlı tarihi, s. 155; Aguilers, Haçlılar Kudüs'te, s. 203; Runciman, Haçl Seferleri Tarihi, 2008, 1: 220. 
görünce olanları fark edip büyük bir sevinç içinde şehre girdiler. Biran bile duraksamadan yoldaşlarına katılıp düşmanları kovalamaya ve katletmeye başladılar."21

Tavır ve davranış olarak haçlıların farklı/aklı selim davranmalarını beklemek beyhudeydi. Çünkü amaçları sadece bir yeri ele geçirip orada hakimiyet tesis etmek ya da oranın ekonomik imkanlarından istifade etmek değildi. Haçlılar bölgeye bir daha geri dönmemek üzere gelmişlerdi. Kont ve düklerde olduğu gibi zengin veya sıradan insanların büyük çoğunluğu da sadece haccetmek veya görev amacıyla sefere katılmak için gelmemişlerdi. Zenginler Batı' daki bütün varlıkların bir daha dönmeyecek şekilde terk etmiş, herhangi bir varlığı olmayanlar da bölgede zenginlikler elde edip oraya yerleşmek için gelmişlerdi. Dolayısıyla büyük umutlarla bölgeye gelen haçlıların yerleşmeleri için insansız şehirlere ihtiyaçları vardı. Bunu sağlamanın en kolay yolu da ele geçirdikleri şehirlerdeki insanları toplu kıyımdan geçirmekti. Hele de söz konusu olan Kudüs olunca asırlardır pis ayaklarıyla kutsal beldeyi kirleten kafirlere yapılacak tek muamele katliam olmalıydı. Çünkü asırlardır kirlettikleri yerler ancak onların kanlarıyla temizlenebilir, adalet sadece bu yolla sağlanabilirdi. ${ }^{22}$ Haçlıların merhamet ettikleri Müslümanlar boyunları vurulup hemen öldürülenler ve oklarla hedef alınıp surlardan düşenlerdi. Daha az şanslı olanlar işkenceye uğrayıp ateşte cayır cayır yakılmışlardı. ${ }^{23}$ Nitekim hem Godefroi'nin hem de Raymond'un adamları görevlerini hakkıyla yerine getirmekten çekinmeyeceklerdir. Willermus bunların bir kısmının ismini verdikten sonra şu ifadeleri kullanmaktadır:

"Bunlar dişlerine kadar silahlı ve tamamen zırhlı olarak hep birlikte şehre girdiler ve çok müthiş bir katliam gerçekleştirdiler. Dükten ve adamlarından kaçıp, hayatlarını kurtarmış olduklarını zannedenler, şehrin diğer tarafına yöneldiklerinde, şimdi bunların ellerine düştüler...Böylece şehirde o kadar çok insan öldürülüp, o kadar çok kan döküldü ki, galiplerin kendileri bile dehşete düştüler."24

\footnotetext{
21 Fulcherius, Kudüs Seferi, s. 104.

22 Guibert, The Deeds of God Through the Franks, 132; Willermus, Haçlı Kroniği, ss. 51$52,363$.

23 Aguilers, Haçlılar Kudüs'te, s. 204.

24 Willermus, Haçl Kroniğ i, s. 362.
} 
Galiplerin dehşete düşmesi katliam esnasındaki duygu olmamalıdır. Zira dönemin kaynaklarının neredeyse tamamı şehirde yapılanları büyük bir keyifle yazmaktadır. ${ }^{25}$ Willermus'un, haçıların dehşete düştükleri cümlesi uzun tecrübeler sonrası oluşan düşünceyi yansımaktadır. Süreç içerisinde bölgeye yerleşen fakat zamanla burada kalıcı olmanın zorluklarının farkına varan müellif, geriye dönüp baktığında yapılanın büyük bir katliam olduğunu kabul etmek zorunda kalmıştır. Yine de yukarıdaki ifadesine rağmen geleneksel haçlı zihniyetini devam ettirdiğini; ordu şehirde dağıldı ve dar sokaklarda gizlenmiş olanları bulup, sığır gibi kestiler, ${ }^{26}$ cümlesiyle gözler önüne sermektedir. Bu ifadeye rağmen önce Nureddin'in sonra da Selahaddin'in mücadelesi sonucu haçlılar oldukça sıkışmış, 1099 yılında yapılan vahşetin benzerinin kendi başlarına da geleceğini düşünmüş olmalılar. Ayrıca bölgeye geldikleri ilk andan itibaren katliamcı bir grup görüntüsü vermeleri süreç içerisinde Müslümanların sert karşılık vermelerine sebep olmuş, yaptıkları katliam sonucu şehirler ve köyler boşalmış, onların yerine haçlıların ihtiyaç duydukları nüfus gelmemişti. Böylece bölgede yalnızlaşmış, günlük ihtiyaçlarını bile karşılamada zorluklar çekmeye başlamış, ihtiyaçlarını ancak Müslümanlarla yaptıkları antlaşmalarla gidermeye çalışmışlardı. ${ }^{27}$ Öte yandan bu cümleden anlaşıldığı kadarıyla haçlılar yaptıkları katliamın boyutlarının ne kadar büyük olduğunu yarım asır sonra fark etmiş ve bunun karşılığının mutlaka olacağını anlamışlardı. Muhtemelen haçlıların düşündüğü karşılık geleneksel zihniyetlerini yansıtan karşı bir katliam olacaktı, fakat Kudüs'ü fetheden Selahaddin'in tavrı onlar için beklenmedik bir durumdu.

25 Ralp of Caen, The Gesta Tancredi of Ralph of Caen: A History of the Normans on the First Crusade, çev.: Bernard S. and David S. Bachrach (England: Ashgate Publishing, Ltd., 2010), s. 148; Anonim, Anonim Haçl tarihi, ss. 156-157; Fulcherius, Kudüs Seferi, s. 105; Guibert, The Deeds of God Through the Franks, ss. 131-132; Aguilers, Haçlılar Kudüs'te, ss. 204, 207-209; Willermus, Haçlı Kroniğ̈i, s. 363.

26 Willermus, Haçlı Kroniğ i, s. 363.

27 The conquest of Jerusalem and the Third Crusade, çev.: Peter W Edbury, (Aldershot: Ashgate Pub., 1998), ss. 16-17; Ernoul, Haçlı Seferleri Tarihi, s. 111. Haçlıların Selahaddin Eyyubi döneminde yapı̆̆ı antlaşmalar için bkz., Ziya Polat, Salâhaddin Eyyûbî'nin Haçlı Siyaseti ve Kudüs Haçlı Krallığıyla Yaptı̆̆ı Antlaşmalar (Doktora Tezi, İstanbul Üniversitesi Sosyal Bilimler Enstitüsü, 2015). 
Nitekim Selahaddin'in tavrı bugünkü batılı haçlı tarihçiler tarafından alkışlansa da yeterince anlaşılamadığı görülmektedir. ${ }^{28}$ Haçlılar şehre girdikten sonra son sürat katliamlarına devam etmekteydi. Anonim haçlı vakayinamesi şehre ilk girenlerin yaptıklarını şöyle tasvir etmektedir:

“...savunmadakiler surların uzağına ve şehre kaçtılar ve bizimkiler de onların arkasından gittiler ve bileklerine kadar düşman kanı içinde yüzdükleri bir katliamın yapıldığı Süleyman Mâbedi'ne kadar onları kestiler."29

$\mathrm{Bu}$ ifadelerde görüldüğü gibi kaynaklar Kudüs'te yaşananları hiçbir rahatsızlık duymadan normal hatta olması gereken bir olaymış gibi aktarmaktadır. Üstelik şehirde yapılan vahşet ve katliam konusunda tümü birbirini destekleyen bilgiler vermektedir. Şehre giren haçlı askerleri gözü dönmüş gibi ele geçirdikleri bütün canl1ları kıyımdan geçirmiş, hedefte olanların asker, kadın, çocuk ya da yaşlı olması farklı bir muameleyi gerekli kılmamıştı. Çünkü kuşatma esnasında yapılan toplantıların birinde şehir paylaşılmıştı. Buna göre kuşatma başarılı bir şekilde sonuçlanır da haçlılar şehre girebilirse herkes istediği eve el koyabilecekti. Kim önce bir eve girerse o ev onun olacak, diğer bir haçlı askeri onda herhangi bir hak iddia etmeyecekti. ${ }^{30}$ Bunun için de dışarda savaşmayıp, evlerinde oturan kadın ve çocukları da evin kendisine ait olduğunun tescili olarak öldürdüler. Şehirdeki katliamdan kurtulur düşüncesiyle binlerce insan Mescid-i Aksa ve Kubbetüsshra'ya sığındılar. Fakat anlatılarda onların da aynı akıbete uğradığı görülmektedir. Fulcherius burada yaşananları şöyle tasvir etmektedir:

"Süleyman Tapınağının çatısından atlayarak kaçmaya çalışan Müslümanların çoğu oklarla vurularak öldürülmüştü. Bu tapınakta yaklaşık on bin Müslüman'ın boynu vuruldu. Burada olsaydınız ayak bilekleriniz katledilenlerin kanlarıyla

Malcolm Cameron Lyons - D. E. P. Jackson, Selahaddin Kutsal Savaşın Politikaları, çev.: Zehra Savan, (İstanbul: Pınar Yayınları, 2006), ss. 325-336. Lyons'un, Selahaddin'in Kudüs'ün fethindeki tavrıyla ilgili herhangi bir cümlesinin olmaması dikkat çekicidir. Fakat daha önceki haçlı tarihçileri Selahaddin'in ne yaptığını anlamamış olsalar da Kudüs'ün ferhindeki olumlu tavrına saygı duyarlar. Mesela Runciman, Onun bu merhamet ve iyiliği, Haçlı seferine iştirak eden Hıristiyan galiplerin kötülükleri ile garip bir tezat teşkil etmekteydi" cümlesini kurmaktadır (Runciman, Haçlı Seferleri Tarihi, (Ankara: Türk Tarih Kurumu, 2008), 2: 391).

30 Willermus, Haçlı Kroniği, ss. 363-364; Fulcherius, Kudüs Seferi, s. 105. 
lekelenebilirdi. Müslümanların hepsi, kadın çocuk ayırt edilmeden, katledildi." 31

Bir önceki alıntıda ifade edildiği gibi Süleyman Mabedi'ne/Mescid-i Aksa'ya kadar yapılan katliamın haçlıları tatmin etmediği anlaşılmaktadır. Anonim haçlı müellifi burada yapılan katliamı tanımlamak için mabedin her yerinden kan damlıyord $u^{32}$ ifadelerini kullanarak yapılan vahşeti adeta büyük bir keyifle resmetmektedir. Mescid-i Aksa'da yapılanları Willermus da benzer ifadelerle tasvir etmektedir; ...halkın bir bölümü tapınağın salonuna kaçtı...Fakat bu kaçış onları kurtarmadı çünkü Tankred ordunun çok büyük bir kısmıyla oraya gitti. Ceben tapınăga girip, sayısız insan katletti. ${ }^{33}$ Oysa dini mabetler kutsallığın ve mahremiyetin sağladığı koruma altında dokunulmaz olarak görülmekteydi. Oraya sı̆̆ınan insanlar kutsallığa ve mahremiyete sığındıklarından canlarını koruma altına almış addediyorlardı. Fakat haçlılar için bunun hiçbir anlamı yoktu. Amaçlarını gerçekleştirmenin önünde hiçbir kutsallık veya mahremiyet duramamış, insan olma vasıflarını bir kenara bırakmışlardı.

Haçlıların kini sadece Müslümanlara yönelik değildi. Müslümanlar şehirde savunma hazırlıkları yaparken muhasara edenlerin Hıristiyan olmasına binaen şehirdeki dindaşlarına güvenilemeyeceği düşüncesiyle insani bir koruma duygusuyla onları surların d1şına çıkarmış, fakat meskûn Yahudilere dokunmamışlardı. İşte bu durum haçlıların dikkatini çekmiş, seferin hazırlık aşamasından bu yana var olan Yahudi düşmanlığg burada da nüksetmiş, Müslümanların Yahudileri dışarı çıkarmamasını ihanet olarak görmüşlerdi. Müslümanlarla birlikte aynı muameleye maruz kalan Yahudiler hakkında İbnü'l-Kalânisi şu ifadeleri kullanmaktadır; ... birçok insan öldürüldü, Yahudileri bir sinagog'a toplayıp ateşe vererek toplu bir şekilde yaktılar. ${ }^{34}$ Nitekim bu olaydan sonra haçliların Yahudilerin bir daha Kudüs'e girmelerine müsaade etmediği bilinmektedir. Yahudiler

31 Fulcherius, Kudüs Seferi, s. 104.

32 Anonim, Anonim Haçl tarihi, s. 156.

33 Willermus, Haçı Kroniği, s. 363. Aynı sayfadaki bu ifadeler de Willermus'a aittir; “şehrin öbür kısımlarını ele geçirdikten ve katliam yaptıktan sonra diğer prensler de tapınağa gittiler, onların arkasından kaçan ahali de gizlendi bunlar bir miktar atlı ve piyadelerle içeri girip, ayırt etmeksizin kime rastladılarsa kılıçtan geçirdiler ve her tarafı kan doldurdular."

34 İbnü'l-Kalânisî, Târîhu Dımaşk, ed.: Süheyl Zekkâr (Dımaşk: Dârü Hassân, 1983), s. 222 . 
ancak Selahaddin Eyyubi'nin Kudüs'ü yeniden fethinden sonra şehre girebileceklerdir.

Haçlılar kuşatma esnasında anlaştıkları gibi Kudüs'e kolayca yerleşebilmek için şehirde hiçbir canlı bırakma niyetinde değillerdi. Şehirde o kadar çok insan öldürmüşlerdi ki artık yorgunluktan halsiz düşmüş, yaptıkları katliam dolayısıyla kan havuzunda yüzmüş gibi her taraflarından kan damlıyordu. Buna rağmen haçlılar katlettiklerini yetersiz görmüş olmalılar ki herkesi öldürmeye ahdetmişçesine şehirde canlı aramakta, bir din adamı olan Fulcherius da; adamlarımız ellerinde yorgun kılıçlarıyla şehrin her yanını dolaşıp hiç kimseyi ayırt etmiyor merhamet dileyenleri bile öldürüyorlardı, ifadeleriyle onların yaptıklarını tasvir etme çabasına girmekteydi. Hatta müellif bunun da ötesine giderek şehirde öldürülen masum insanlarla dalga geçip; halk sallanan dallardan düşen çürük elmalar ve meşe palamutları gibi hayatlarını kaybediyordu, ${ }^{35}$ kaydını düşerek yapılandan ne kadar memnun olduğunu da gözler önüne sermektedir. Dönemin kaynaklarından biri olan Guibert'in de dindaşlarından farklı bir bakış açısına sahip olmayıp büyük bir hırsla şehre giren haçlılar için; vahşice kaçanları takip edip önlerine çıkan herkesi öldürdüler, bu bir savaştan ziyade tam bir katliamd ${ }^{36}$ ifadelerini kullanarak durumu izah etmektedir.

Haçlılar yapılan katliamın normal bir davranış olmadığının farkındaydı. Tanrı adına kutsal toprakları kurtarmak için çıktıkları seferde yaptıklarını dini inançlarına dayandırarak açıklamaları muhtemelen onları psikolojik açıdan rahatlatmaktaydı. Bunun için yapılan vahşeti kendilerinden değil de Tanrı'dan gelen bir ceza olarak açıklama çabasına girmekteydiler. Hatta öyle ki Raimundus; bana kalırsa onca yıldır Süleyman Mabedi'nde Tanrıa küfreden putperestlerin kanının, mabette dökülmesi şairane bir adalet, ${ }^{37}$ diyerek katliamin hangi zihniyet üzerinden işlendiğini gözler önüne sermektedir. Aynı şekilde Willermus'un yapılan katliama bulduğu gerekçe kendi ifadesiyle en az katliamı yapanların fiilleri kadar korkunçtur: $B u, b a-$ tıl inançlarıyla Rabb'in kutsalın kirletenlerin ve müminleri mahrum bırakanların günahlarının kefaretini ölümleri ve kanlarıla temizlemeleri için,

\footnotetext{
35 Fulcherius, Kudüs Seferi, s. 105.

36 Guibert, The Deeds of God Through the Franks, s. 130.

37 Aguilers, Haçlilar Kudüs'te, ss. 207-208.
} 
Tanrı'nın adaleti idi. ${ }^{38} \mathrm{Bu}$ nasıl bir adalet anlayışı ki hiçbir şeyden haberi olmayan masum çocukların bile kılıçtan geçirilmesini olması gereken bir durum olarak tasvir etmektedir.

Kaynaklar adalet olarak gördükleri katliamın manzarasını tasvir etmek için olabildiğince cömert ifadeler kullanmışlardı. Raimundus; evlerde, sokaklarda yı̆̆ın yı̆̆ın başlar, eller ve ayaklar uzanıyordu; askerlerin ve şövalyelerin üstlerinde bir aşă̆ı bir yukarı koşturdukları aslında cesetlerdi, ${ }^{39}$ cümlesiyle katliamdan hiçbir rahatsızlık duymad1ğını keyifli bir şekilde anlatmaktadır. Willermus galiplerin görüntüsünü; her yerde yatan cesetlere ve kanla örtülen insan uzuvlarına bakmak korkunçtu. Ve sadece parçalanmış cesetler ve kesilmiş kafalar kötü bir manzara teşkil etmiyor, baştan ayağa kana bulanmış galiplerin görüntüsü de ürpertiyord $u^{40}$ cümleleriyle çarpıcı bir şekilde resmetse de geleneksel haçlı zihniyetinin dışına çıkamamıştır. Sadece askerler değil, şehirde kanın bulaşmadığ redi'nin yazarı Radulphus yaşanan vahşeti anlatmak için; kapılar, duvarlar, koltuklar, masalar ve sütunlar tamamen kanla boyanmıştı, ${ }^{41}$ ifadesini kullanmaktadır. Bütün bunları ifade edebilecek en net cümle Willermus tarafından kurulmuştur. Ona göre Kudüs'te yapılan katliam karşısında; galiplerin kendileri bile dehşete düştüler. ${ }^{42}$ Müellifin bu ifadesi amaçlarıyla fiillerinin tenakuzunu gösterdiği gibi haçlıların hangi psikoloji ile hareket ettiklerini de ortaya koymaktadir.

\section{Katliamın Niceliği}

Şehirde ne kadar insanın öldürüldüğüyle ilgili farklı rakamlar telaffuz edilmektedir. Hem Müslüman hem de haçlı tarihçilerinin anlatılarına bakıldığında otuz ile yüz bin arasında farklı rakamların kayda geçirildiği görülmektedir. Raimundus şehrin düşmesinden önceki son saldırıda verdiği bilgilere göre şehirde en iyi ihtimalle savaşabilecek durumda altmış bin kişi olduğunu, bunlara kadın ve çocukların dahil olmadığını ifade etmektedir.43 Buna göre şehirde yüz bin civarında insan yaşamaktaydı. Anonim haçlı tarihi herhangi bir sayı vermemekle birlikte şehirde öldürülenler hakkında; ne kadar

\footnotetext{
Willermus, Haçlı Kroniği, s. 363.

Aguilers, Haçlilar Kudüs'te, s. 204.

Willermus, Haçlı Kroniğ i, s. 363; Ralp of Caen, The Gesta Tancredi, s. 143.

Ralp of Caen, The Gesta Tancredi, s. 148.

Willermus, Haçlı Kroniğ i, s. 362.

Aguilers, Haçlilar Kudüs'te, s. 200.
} 
çok olduklarını yalnız tanı bilir, ${ }^{44}$ ifadesini kullanarak sayının büyüklüğü hakkında yorum yapmakla yetinmiştir. Fulcherius şehrin bütününde öldürülenlerden bahsetmez fakat Süleyman Tapınağı olarak ifade ettiği Mescid-i Aksa'da on bin civarında insanın öldürüldüğü bilgisini paylaşmaktadır. ${ }^{45}$ On ikinci asrın ortalarından sonra eserini kaleme alan Willermus bu ifadeleri destekleyerek sadece Mescid-i Aksa'nın avlusunda on bin civarında Müslümanın katledildiğini ve şehir içinde öldürülenlerin de bunlardan daha az olmadığı bilgisini vermektedir. ${ }^{46}$ Yerli Hıristiyan kaynaklara bakıldığında Urfalı Mateos şehrin içinde öldürülenlerin dışında mabette altmış beş bin kişinin kılıçtan geçirildiği bilgisini vermektedir. ${ }^{47}$ Meçhul Süryani vakanüvis ise şehirde otuz bin Müslümanın öldürüldügüünü söylemektedir. ${ }^{48}$ Dolayısıyla hem haçlı hem de yerel H1ristiyan kaynakların verdiği bilgilere bakıldığında sayının yukarıda ifade edilen rakamlardan farklı olmadığı görülecektir. Bu sayı da söz konusu asırlar göz önünde bulundurulduğunda çok büyük rakamlar olduğu anlaşılmaktadır.

Haçlı kaynaklarının açık bir şekilde verdiği bilgilere rağmen Hillenbrand, Kudüs'te yapılan katliamla ilgili Müslüman tarihçilerin anlatılarının süreç içerisinde gittikçe abartılı bir dil kazandığı düşüncesindedir. ${ }^{49}$ Azîmî konuyu aktaran en eski kaynaklardan biri olmakla birlikte verdiği bilgi çok kısadır. Müellif eserinde şehrin zapt edildiği ve Yahudilere ait bir sinagogun yakıldığ bilgisini vermekle yetinir. ${ }^{50}$ Müellifin bu aktarımı Kudüs'teki katliamı önemsiz kılmadığı gibi onu yok saymaya da sebep olamaz. Çünkü eser karakter bakımından özet bilgiler üzerinden inşa edilmiştir. Eserin yapısı gereği ondan ayrıntı beklemek usule aykırı olacaktır. Kudüs'ün zaptını kaydeden en eski müelliflerden biri de İbnü'l-Kalânisi'dir. Müellif eserinde olayı özet bir şekilde anlatmakla birlikte haçlılar ele

\footnotetext{
44 Anonim, Anonim Haçlı tarihi, s. 158.

45 Fulcherius, Kudüs Seferi, s. 104.

46 Willermus, Haçlı Kroniği, s. 363.

47 Urfalı Mateos - Papaz Grigor, Vekayiname, s. 199.

48 I. ve II. Haçlı Seferleri Vekayinamesi, çev.: Vedii İlmen, (İstanbul: Yaba Yayınları, 2005), s. 14.

49 Carole Hillenbrand, Müslümanların Gözünden Haçlı Seferleri, çev.: Nurettin Elhüseyni (İstanbul: Alfa Tarih, 2015), s. 93.

50 Muhammed b. Ali Azîmî, Târîhu Haleb, ed.: İbrahim Za'rûr (Dimaşk, 1984), s. 360.
} 
geçirdikten sonra şehirde birçok insanın öldürüldüğünü ve Yahudilerin sinagoga toplanarak yakıldığı bilgisini vermektedir. ${ }^{51}$ Olayı aktaran bir diğer kaynağımız İbnü'l-Cevzi'nin el-Muntazam adlı eseridir. Kudüs'teki katliamla ilgili rakam veren ilk Müslüman tarihçidir. Ona göre şehirde yetmiş binden fazla insan öldürülmüştür. ${ }^{52}$ İbnü'1-Esîr de bazı ayrıntılarla birlikte aynı rakamı vermekte ve bunların içinde birçok alim ve zahidin bulunduğu bilgisini eklemektedir. ${ }^{53}$ Hillenbrand'ın ilk kaynaklarda sayı ile ilgili bilgi olmadığ1 tespiti kısmen doğru olmakla birlikte Vali İftiharüddevle ve maiyeti dışında şehirden hiç kimsenin canlı çıkmaması Müslüman tarihçilerin birinci elden bilgi almalarını zorlaştırmış, kayda geçtikleri bilgilerin uzun süren bir periyotta elde edilmiş olması duygusallı̆̆ı ön plana çıkmasına sebep olmuştur. Fakat öte yandan Müslüman tarihçilerin verdikleri bilgiler görgü şahitlerinden aktarılmamasına ve ifade edilen olumsuzluklara rağmen haçlı kroniklerinin anlatımlarıyla çelişmemektedir. Dolayısıyla verilen rakamların abartı olmadığı gibi şehirdeki katliamın boyutlarının iki taraf açısından doğru bir şekilde tespit edildiği anlaşılmaktadır.

\section{Haçlı Seferinin Amacı ve Katliam}

Haçlların seferin başlangıcından itibaren dini bir amaç peşinde oldukları varsayıldığında şehirde yapılan dehşet verici katliamı da aynı sebeplerle açıklama zorunluluğu ortaya çıkmaktadır. Oysa şehirde bir yandan katliam sürerken diğer yandan seferin liderlerinin ganimet elde etme ile ilgili tavırlarının izaha muhtaç olduğu görülmektedir. Sefer boyunca ele geçirilen yerlerin kime ait olacağı konusunda haçlı liderleri arasında büyük tartışmaların yaşandığı kaynaklar tarafından ifade edilmektedir. Raimundus yaşananları; Kale ve köşk kapma tamahkârlı̆̆ımızın neden olduğu delicesine mücadele, ${ }^{54}$ şeklinde kayda geçerek durumu özetlemiştir. Öte yandan haçlı liderleri arasındaki mücadelenin sadece kale ve köşk kapma yarışı olmadığ1 ele geçirilen yerlerdeki ganimet konusunda da büyük tartışmaların yaşandığı belirtilmelidir.

\footnotetext{
51 İbnü'l-Kalânisî, Târîhu Dımaşk, s. 222.

52 Ebü'l-Ferec İbnü'l-Cevzi, el-Muntazam fi târîhi'l-mülûk ve'l-ümem, thk.: Muhammed Abdülkadir Ata, Mustafa Abdülkadir Ata, (Beyrut: Dârü'l-kütübi'l-ilmiyye, 1995), 17: 47.

53 İbnü'l-Esîr, İslâm Tarihi: el-Kâmil fi't-Târîh Tercümesi, çev.: Abdülkerim Özaydın, (İstanbul: Bahar Yayınları, 1991), 10: 236.

54 Aguilers, Haçlılar Kudüs'te, s. 188.
} 
Yukarıda ifade edildiği gibi haçlılar şehir içinde yaptıkları katliamla yetinmemiş, evlerinde masum bir şekilde oturan ya da haçl1ların şehre girmesinden sonra daha fazla direnmenin anlamsız olacağını düşünüp evlerine sığınan insanları da hedeflerine koymuşlardı. Willermus bunu; diğerleri birleşip evlere girip, ana, baba, çocuk ne varsa dışar çıkarıp ya kılıçlarla öldürdüler ya da çatılardan aşağ atıp boyunlarımı kırdılar, ${ }^{55}$ ifadeleriyle açıklığa kavuşturur. Evlerine sığınan insanlara yapılanlar haçlıların bölgeye niçin geldiklerini açıklar mahiyettedir. Nitekim müellifin kendisi hemen devamında; Girdikleri evleri mülk edindiler, çünkü şehir zapt edildikten sonra ele geçirdiklerini yasal mülkiyet edinme hususunda birbirleriyle anlaşmışlardı. Böylece kente girip, halkın evlerini ve gizli sığınaklarm ele geçirdikten sonra, herhangi birisi geldiğinde burasının bir sahibi olduğunu anlasın ve yoluna devam etsin diye kaprya bir kalkan veyahut herhangi bir silah astyordu ${ }^{56}$ anlatısıyla durumu gözler önüne sermektedir.

Ganimet ve mal elde etme hırsı haçlılara sadece katliam yaptırmakla yetinmedi. Katlettikleri insanların cesetlerine bile akla hayale gelmedik vahşetler uygulandı. Gözlerini mal ve ganimet hırsı bürümüş haçlılar, Müslümanların mallarına canlarından daha fazla değer verdiklerini düşünmüş olmalılar ki maddi servetlerini korumaları için her yola baş vurduklarını düşünmekteydiler. Fulcherius'un konu hakkındaki anlatısı dehşet vericidir: Müslümanların hilelerini keşfeden şövalyelerimiz ve yayalar, Müslümanlarm yaşarken ĭgrenç boğazlarından yuttukları, Bizans sikkelerini bağırsaklarından çıkartmak için bunları öldürür öldürmez karınların deştiler. ${ }^{57} \mathrm{Bu}$ tavır aynı zamanda haçlıların içinde bulunduğu psikolojiyi yansıtmaktadır. Maddi servetlerini korumak için kendilerinin davranış olarak sergilediklerini Müslümanların da yapacaklarını düşünmüş olmalılar. Öte yandan cesetlere uygulanan vahşet Batı'daki Hıristiyanların içinde bulunduğu ekonomik durumu gösterdiği gibi haçlıların niçin yola çıktıklarını da açıklamaktadır. Nitekim İncil'de yazıldığı gibi kutsal topraklarda sokaklarından bal ve süt akan şehirler olduğu efsanesi haçlı seferine katılanlar için motive edici bir güç olmuş, oraya ulaşabilenlere buralardaki zenginliklere sahip olacakları ifade edilmişti. Çünkü Batı'daki Hıristiyanların yaşadıkları topraklar onları

\footnotetext{
55 Willermus, Haçlı Kroniğ i, s. 363.

56 Willermus, Haçlı Kroniğ i, ss. 363-364.

57 Fulcherius, Kudüs Seferi, s. 105.
} 
doyurmadığı gibi var olanı da elde etmek için birbirleriyle savaşıp tahrip ediyorlard1..$^{58}$ Böylece yoksullukları bir kısır döngü şeklinde devam ediyordu. İşte bunu aşmanın yollarından biri haçlı seferine katılıp Doğu'daki zenginliklere sahip olmaktan geçiyordu. Nitekim Anna Kommena da bu fikirlerini açk bir şekilde ifade etmiştir. Ona göre haçlılar görünüşte Kudüs'e sefer yapıyorlardı ama asıl amaç Doğu Roma İmparatorunu tahtından etmek ve maddi güç elde etmekti. ${ }^{59}$ Müellifin bu düşüncesi abartılı olsa da haçlıların maddi imkan elde etme hedeflerini gözler önüne sermektedir.

Kaynaklardaki anlatılar bunlarla sınırlı kalmamaktadır. Haçlılar ganimet elde etme hırsıyla dehşeti öyle ileri bir seviyeye taşıdılar ki yapılanları dini gerekçe veya mal elde etme hırsıyla açıklamanın imkânı kalmamaktadır. Öldürmüş oldukları Müslümanların karınları deşilerek altın arama faaliyetleri haçlıları tatmin etmemiş olmalıdır ki az sayıda öldürmeyip esir aldıkları Müslümanlar eliyle parçalanmış cesetleri muhtemelen şehir dışında büyük yığınlar halinde topladılar. ${ }^{60}$ Fulcherius bu faaliyeti; yine aynı amaçla cesetleri büyük yı̆̆ınlar halinde toplayıp yakarak küller arasındaki altınları kolaylıkla buldular, ${ }^{61}$ cümlesiyle açıklamaktadır. Diğer bir kaynak olan Anonim Haçlı Tarihi verdiği bilgilerle manzarayı tamamlamaktadır: böyle bir imansız katliamı şimdiye kadar ne görülmüss ne de işitilmişti, zira odun yığınları üzerinde yanan piramitlere benziyorlardı. ${ }^{62}$ Haçlılar altın bulma ümidiyle şehirdeki cesetleri yakıp aramalarını bitirdikten sonra esir aldıkları Müslümanları da kılıçtan geçirdiler. ${ }^{63}$ Onlar sadece kullanılmak için sağ bırakılmışlardı. Görevlerini yaptıktan sonra hayatta kalma hakları da sona ermiş oldu.

Katliamın tek sebebi şehirdekilerin Müslüman olması değildi. Eğer öyle olsaydı, Raymond, şehir düştükten sonra Davut Kulesi'ne sığınan İftiharüddevle ile sıkı bir pazarlığa girişmezdi. Her ne kadar teklif savunma yapanlardan gelmiş olsa da Raymond elde edeceği maddi menfaat karşıllı̆̆ında içerdekiler Müslüman da olsa onlarla pazarlık yapmış, yapılan antlaşma sonucu kule içindekilerle birlikte

\footnotetext{
58 Işın Demirkent, Haçlı Seferleri, 1. bs., (İstanbul: Dünya Aktüel, 2004), s. 8.

59 Komnena, Alexiad Malazgirt'in Sonrası Imparator Alexios Komnenos Döneminin Tarihi, s. 313 .

Anonim, Anonim Haçl tarihi, s. 158.

Fulcherius, Kudüs Seferi, s. 105.

Anonim, Anonim Haçl tarihi, s. 158.

Guibert, The Deeds of God Through the Franks, s. 131.
} 
teslim edilmiş, vali ve maiyeti güvenli bir şekilde Askalan'a gitmişlerdi. ${ }^{64}$ Raymond'un bu tavrı bazı haçlı kaynakları tarafından eleştirilmiştir. Özellikle Albertus, Raymond'un İftiharüddevle ile yaptığ pazarlığı ahlaksızlık olarak görmüş; onu rüşvet almak, açgözlülük ve yolsuzluk yapmakla suçlamıştır. ${ }^{65}$

Haçlılar katliamdan sonra şehri cesetlerden temizleyip ganimetlerin paylaşılmasını bitirdikten sonra bölgeye niçin geldiklerini hatırladılar. Willermus; böylece şehirde düzen kurulduktan sonra silahları bıraktılar, ellerini yıkadılar, temiz giysiler giydiler, mütevazı ve nadim kalplerle, ă̆layış ve hıçkırıklarla, yalınayak olarak, kurtarıcının varlığıyla takdis ettiği mukaddes yerlere gittiler ve buraları büyük bir saygı ile öptüler, 66 demektedir. Bu esnada asırlardır şehirde yaşayan Hıristiyanlar, yeni gelenleri büyük bir coşkuyla karşılayıp onlara teşekkürlerini ilettiler. Oysa savaş durumu olmasına rağmen şehirdeki Müslümanlar sadece onları şehirden çıkarmakla yetinmişlerdi. Güçlerinin yetip yetmeyeceği tartışılabilir ama yerli Hıristiyanların şehirdeki bütün Müslümanların katledilmesinden rahatsız olmadıkları anlaşılmaktadır, çünkü kaynakların hiçbirinde bununla ilgili herhangi bir ifade yer almamaktadır. Dönemin yerli Hıristiyan kaynakları şehirde katledilen Müslümanlar hakkında herhangi bir üzüntü cümlesi kurmamaktadır. Mesela Urfalı Mateos şehirdeki katliamdan bir cümle ile bahsettikten sonra; mukaddes şehir bu suretle zaptedildi ve hazreti İsa'nın kabri Müslümanların boyunduruğundan kurtarıld $\imath,{ }^{67}$ ifadesiyle durumdan memnun olduğunu beyan etmektedir. Fakat bütün yerli kaynakların bu bakış açısına sahip olmadığı bilinmektedir. Mesela anonim Süryani vakayinamesi sadece Kudüs'ün düşüşünden ve şehirde ne kadar insanın katledildiğine değinmekle yetinmesine rağmen, bu esnada şehirde büyük bir yıkımın gerçekleştiği bilgisini de vermiştir. ${ }^{68}$

\section{Sonuç}

Papa II. Urbanus'un çağrısını yaptığı 1095 tarihine gelindiğinde haçlı seferlerinin psikolojik alt yapısı hazır halde bulunmaktaydı.

64 Anonim, Anonim Haçlı tarihi, s. 158; Aguilers, Haçlılar Kudüs'te, s. 208; Guibert, The Deeds of God Through the Franks, s. 131.

65 Albert of Aachen, Historia Ierosoliminata: History of the Journey to Jerusalem, s. 439.

66 Willermus, Haçl Kroniğ i, s. 365.

67 Urfalı Mateos - Papaz Grigor, Vekayiname, s. 199.

68 I. ve II. Haçlı Seferleri Vekayinamesi, ss. 13-14. 
Bunu oluşturan temel argüman İslam Fetihlerin kılıçla yapıldığı algısıydı. Buna göre Müslümanlar Hiristiyanların hakimiyetindeki topraklara kılıç zoruyla hâkim olmuş, birçok Hıristiyan öldürmüş, kiliseleri ve kutsal yerleri tahrip etmişti. Bu zulümler ve kutsal yerlerin işgali asırlardır devam etmekteydi. Bugüne kadar kilisenin tepki vermemesi güçsüzlüğünden kaynaklanmaktaydı. Bunu aşmanın yolu da dine yani kiliseye eski gücünü kazandırmaktan geçmekteydi. Bu da doğuya yapılacak bir seferle kutsal beldelerin Müslümanların işgalinden kurtarılmasıyla gerçekleştirilecekti. İslam fetihlerinin kılıçla olduğu iddiası daha çok Haçlı seferlerinin altyapısın oluşturan bir sebep olarak inşa edilmiştir. Çünkü ilk dönem Hıristiyan kaynaklarında böyle bir iddia yer almamaktadır. Muhtemelen Müslümanların çıkışını geçici bir durum olarak algılayan Batılı Hıristiyanlar, asırlar sonra onların kalıcı olduklarını fark ettiklerinde savunma hatları oluşturmaya başlamışlardı. Bunlar içerisinde en dikkat çekeni İslam fetihlerinin kılıçla olduğu iddiasıdır. Buna göre İslam üç kıtaya kılıç zoruyla yayılmıştır. Dolayısıyla buna aynı sertlikle cevap verilerek İslam tehlikesi bertaraf edilmeliydi.

Papa'nın hitabetinde İslam'ın kılıçla yayıldığı iddiası yer almamakla birlikte Doğu'daki Hıristiyanların savaşlarda yenildikleri ve Müslümanların Marmara kıyılarına ulaştıkları bilgisini vermiştir. Bunun önüne geçmenin yolu da daha şiddetli bir karşıllk vermek olmalıdır. Çünkü kutsal topraklar, kilise ve din, putperestlerin kirli ayakları altında ezilmekte; Doğu'daki Hıristiyanlar asırlardır zulüm görmekteydi. Üstelik Müslümanlar Batılı Hıristiyanlara haccetme izni vermemiş, kutsal topraklara yolculuk yapanlara her türlü sıkıntıyı yaşatmışlardı. Dolayısıyla haçlı seferinin ana teması kutsal beldeleri putperestlerin işgalinden kurtarmak şeklinde ifade edilmiştir. Papa'nın himayesinde başlayan sefer pür dini bir amaç görüntüsüyle yola çıkmış, papalık adına sefere Le Puy Piskoposu Adhemar liderlik yapmakla birlikte birçok dük, kont ve prens de sefere eşlik etmişti. Dolayısıyla dini amaçlarla sefere katılan birçok din adamı ve sıradan insan olmakla birlikte Batı'daki siyasi, sosyal ve ekonomik sıkıntılardan kaçıp zengin olmak ve toprak elde etmek amacıyla sefere katılan sayısız insan vardı. Bunlar içerisinde düzeni bozan paralı serkeş askerle de mevcuttu.

Üç yıl sonra Kudüs önlerine geldiğinde haçlı seferinin ortakları elde ettikleri özgüvenin etkisiyle şehri alacaklarına kesin bir şekilde inanmaktaydılar. Çünkü onlar tanrının emriyle yola çıkmışlardı. 
Dolayısıyla onlara mutlaka yardım edecekti. Haçlılar henüz kuşatma durumundayken yaptıkları toplantının birinde şehri nasıl paylaşacaklarını tartışmışlardı. Buna göre şehre girildiğinde bir eve ilk olarak hangi haçlı girmişse ev onun olacaktı. Böylece hane halkı kılıçtan geçirilecekti. Buna toplantıda bulunan din adamları hiçbir itirazda bulunmadılar. Nitekim 15 Temmuz 1099'da şehre girildiğinde tarihin gördüğü en büyük katliamlardan biri gerçekleştirildi. Davut Kulesinde direnişi sürdüren Vali İftiharüddevle ve maiyeti dışında hiç kimse şehirden canlı çıkamadı. Dinlerin amacı İnsanlara kurtuluş yolunu göstermek olmasına rağmen Kudüs'te bulunan insanlar kadın çocuk demeden kılıçtan geçirildi, kendilerinin bile dehşete düştükleri manzaralar oluştu. Katliam denince haçlıların yaptıklarından bir asır sonra ortaya çıkan Moğollar akla gelmektedir. Oysa onlardan daha önce ilk örnekler haçlılar eliyle gerçekleştirildi. Fakat bugün batı merkezli tarih anlayışından dolayı neredeyse haçlı seferleri haklı gerekçelere dayandırılmakta ve Kudüs'te yapılan katliam sadece birkaç cümle ile geçiştirilmektedir. Dolayısıyla haçlılar dini bir argümanla çıtıkları seferin sonunda hem Kutsal beldeleri ele geçirmiş hem de şehirlerde katliamlar yaparak zenginlikler ve geniş topraklar elde etmişlerdir.

Haçlı seferlerinin psikolojik altyapısı olarak inşa edilen İslam fetihleri asırlarca devam etmiştir. Üç kıtaya yayılan fetihler göz önünde bulundurulduğunda her iki tarafta öldürülenlerin sayısı sadece birinci haçlı seferinde öldürülenlerin sayısı kadar bile değildir. Hatta bir adım daha ileri giderek sadece Kudüs'te öldürülen Müslümanların sayısı tüm fetihlerde ölen insanlardan daha fazla olduğunu söylemek mümkündür. Daha kötüsü Batı'nın katliamcı tabiatı dünden bugüne varlığını devam ettirmektedir. Haçlı seferlerinde nasıl ki din maddi amaca giden yolun aracı olarak dizayn edildi ise bugün de ondan farklı olmayarak demokrasi, insan hakları ve özgürlükler çeşitli milletlerin ve toplumların servetlerine konmanın aracı olarak kullanılmaktadır. Çünkü dün olduğu gibi nasıl ele geçirdikleri şehirlerde katliamlar gerçekleştirip insanların servetlerine kondularsa bugün de bahane edilen kavramlar aracılığıyla bir bölgeye yerleşip maddi servetler kontrol altına alınırken olduğu gibi alındıktan sonra da yüzbinlerce insan ölmeye devam etmektedir. 


\section{Kaynakça}

Aguilers, Raimundus. Haçlılar Kudüs'te Bir Papazın Gözünden İlk Haçlı Seferi, çev.: Süleyman Genç (Yeditepe Yayınevi, 2019).

Albert of Aachen. Historia Ierosoliminata: History of the Journey to Jerusalem, çev.: Susan B. Edgington (Oxford: Oxford University Press, 2007).

Anonim. Anonim Haçlı tarihi, çev.: Ergin Ayan (İstanbul: Selenge Yayınları, 2013).

Azîmî, Muhammed b. Ali. Târîhu Haleb, ed.: İbrahim Za'rûr (Dımaşk, 1984).

Demirkent, Işın. Haçlı Seferleri, 1. bs. (İstanbul: Dünya Aktüel, 2004).

Demirkent, Işın. "Haçlı Seferleri Düşüncesinin Doğuşu ve Hedefleri”. Tarih Dergisi / Turkish Journal of History, (1994), S. 35 ss. 65-78.

The Conquest of Jerusalem and the Third Crusade, çev.: Peter W. Edbury, (Aldershot: Ashgate Pub., 1998).

Ernoul. Haçlı Seferleri Tarihi Selahaddin Eyyubi ve Kudüs'ün Fethi, çev.: Ahmet Deniz Altunbaş (Kronik Kitap, 2019).

Fulcherius, Carnotensis. Kudüs Seferi Kutsal Toprakları Kurtarmak çev :İlcan Bihter Barlas. 1. bs (İstanbul: IQ Kültür Sanat Yayıncılık, 2009).

Guibert, de Nogent. The Deeds of God Through the Franks: A Translation of Guibert de Nogent's Gesta Dei Per Francos, çev.: Robert Levine (Boydell \& Brewer Ltd, 1997).

Hillenbrand, Carole. Müslümanların Gözünden Haçlı Seferleri, çev.: Nurettin Elhüseyni (İstanbul: Alfa Tarih, 2015).

İbnü'l-Cevzi, Ebü'l-Ferec. el-Muntazam fi târîhi'l-mülûk ve'l-ümem. çev. ve thk.: Muhammed Abdülkadir Ata, Mustafa Abdülkadir Ata. 2. bs (Beyrut: Dârü'l-kütübi'l-ilmiyye, 1995).

İbnü'l-Esîr. İslâm Tarihi: el-Kâmil fi't-Târîh Tercümesi. çev.: Abdülkerim Özaydın. 1. bs (İstanbul: Bahar Yayınları, 1991) c. 12.

İbnü'l-Kalânisî. Târîhu Dımaşk, ed.: Süheyl Zekkâr (Dımaşk: Dârü Hassân, 1983).

Komnena, Anna. Alexiad Malazgirt'in Sonrası Imparator Alexios Komnenos Döneminin Tarihi, çev.: Bilge Umar (İstanbul: İnkılap Kitabevi, 1996).

Lock, Peter. The Routledge Companion to the Crusades. (London ; New York: Routledge, 2006).

Lyons, Malcolm Cameron - Jackson, D. E. P. Selahaddin Kutsal Savaşın Politikaları. çev.: Zehra Savan. 1. bs (İstanbul: Pınar Yayınları, 2006).

Polat, Ziya. Salâhaddin Eyyûbî'nin Haçlı Siyaseti ve Kudüs Haçlı Krallığıyla Yaptı̆̆ı Antlaşmalar. Doktora Tezi, İstanbul Üniversitesi Sosyal Bilimler Enstitüsü, 2015.

Ralp of Caen. The Gesta Tancredi of Ralph of Caen: A History of the Normans on the First Crusade, çev.: Bernard S. and David S. Bachrach (England: Ashgate Publishing, Ltd., 2010).

Runciman, Steven. Haçlı Seferleri Tarihi, 4. bs (Ankara: Türk Tarih Kurumu, 2008), c. 3. 
Urfalı Mateos - Papaz Grigor. Urfalı Mateos Vekayi-Nâmesi (952-1136) ve Papaz Grigor'un Zeyli (1136-1162). Çev.: Hrant D. Andreasyan (Ankara: Türk Tarih Kurumu, 2000).

I. ve II. Haçl Seferleri Vekayinamesi, çev.: Vedii İlmen, 1. bs (İstanbul: Yaba Yayınlar1, 2005).

Willermus, Tyrensis. Willermus Tyrensis'in Haçlı Kroniği Başlangıçtan Kudüs'ün Zaptına Kadar, çev.: Ergin Ayan. 1. bs (İstanbul: Ötüken Neşriyat, 2016). 